\title{
POETICA DIVINITĂȚII ÎN VOLUMUL POEMELE LUMINII
}

\author{
Gabriela-Raluca Duță \\ gabriela.duta01@e-uvt.ro \\ Universitatea de Vest din Timișoara
}

\begin{abstract}
The purpose of this work is to analyze, both in terms of interpretation and occurrence, the religious elements of Lucian Blaga's volume "Poems of Light" ("Poemele Luminii"), namely the links between the figures of divinity and the individual, the latter being seen in its inferior, ephemeral condition, which in fact prevents him from identifying with the deity in question, but which does not stop him from aspiring to the absolute.
\end{abstract}

Key-words: divinity, original sin, individual, Genesis, concordances

În volumul Trilogia culturii, Lucian Blaga conturează imaginea unui Dumnezeu impersonal, care există pretutindeni, atât în lume, cât și în noi înşine, determinând declanșarea a două identităţi ale infinitului: un infinit mare, al lumii, dar și un infinit de dimensiuni reduse, interior, din inima noastră (102). Tot acesta susține că individul, respingând caracterul de negație ce poate apărea în cazul acestor identități, se retrage din orizont incert, revărsându-și interesul asupra absolutului, menționând totodată ideea de mântuire drept ,retragere din orizont şi revărsare în impersonal, în absolutul stihial” (Trilogia culturii 411).

Însă, având în vedere procesul de creație, Blaga este de părere că absolutul, divinitatea, transcendentul nu trebuie să intervină sub nicio formă în opera artistică, pentru că acestea ar sublima misterul, ar periclita perfecțiunea unică a operei respective prin încercarea de revelare a conținutului menit să genereze întrebări. $\mathrm{Cu}$ atât mai mult, autorul plasează artistul în planul purului-uman, fără să îl idealizeze în vreun fel (Trilogia valorilor III 60-61). Tocmai această amplasare întărește separarea celor două elemente material (uman) și imaterial (divin), acutizând percepția lui Blaga asupra divinității, în general, drept entitate spre care omul aspiră, dar cu care acesta din urmă nu se identifică, cunoscându-și limitele bine definite.

De unde pornește, atunci, ideea de divinitate la Blaga și cum se conturează poetica acesteia în lirica lui? Unul dintre punctele de plecare este chiar problematica „Marelui Anonim”, coordonată metafizică formulată după modelul kantian (Blaga, Trilogia cosmologică 26-27). Omul nu poate să cunoască absolutul, pentru că „supremul judecător” împiedică acest lucru, străjuind astfel 
misterul înaltului de neatins. Însă, spre deosebire de figura sacră din cultura creștină care propune o triadă desăvârșită ce exprimă de fapt ideea de singularitate, sau viziunea lui Plotin asupra unei existențe unice, nedefinibile, la Blaga apare iluzia unei antinomii (divin-demonic), ce oferă cu totul noi perspective privind transcendentul (Petrescu 92). Având în vedere această distincție, însăși poetica blagiană capătă noi valențe. Elementele biblice, cât și cele ce țin de păgânism nu exprimă aceeași tipică sacralitate lipsită de enigmatic, bine-cunoscută deja de cititor, ci depășesc aceste granițe, urmând o traiectorie experimentală. În timp ce, conform ideii gnostice, Dumnezeu este supremul creator din care, prin procese succesive și degradate, a rezultat omenirea, Blaga îl situează într-un plan ilustru, drept arhitectul logosului, al lumii ideilor pure (din care rezultă ființele superioare), părintele existențelor mijlocii și al celor inferioare (printre care se regăsește și omul), creația sa căpătând o valoare întregită, regăsită sub semnul decadenței. Menirea ființei umane este de a transcende această sferă a inferiorității, de a urca ,panta decadenței cosmice” (Blaga, Trilogia valorilor II 39).

Pentru a face vizibile aceste minore diferențe de „substrat” menționate anterior, am selectat o parte din poeziile regăsite în volumul Poemele luminii, în care se identifică astfel de referințe. Cercetarea are la bază, astfel, și o dimensiune cantitativă, deoarece am utilizat instrumente digitale (Sinclair și Rockwell) în extragerea ocurențelor unor termeni religioși ori specifici sacrului. Comparând frecvența acestora în volumul de debut al poetului și opera completă (lirică), putem face câteva observații care justifică alegerea Poemelor luminii ca manifestare consistentă a poeticii divinității, în sensul referințelor biblice. Spre exemplu, 8 din cele 44 de ocurențe ale formelor Dumnezeu ori dumnezeire sunt prezente aici, la fel ca singura referință directă la demonic (Noi și pământul: „Noi și pământul/ Atâtea stele cad în noaptea asta./ Demonul nopții ține parcă-n mâni pământul"). Mai mult, figurile lui Adam, a Evei și a șarpelui, în contextul păcatului primordial, își găsesc aici cele mai puternice contururi: nu mai puțin de 66\% (Adam), 36\% (Eva), 40\% (șarpe), respectiv 13\% (păcat) din ocurențe se observă în acest prim volum. De asemenea, făcând referire la două regiuni ontologice diferite marcate prin raportul tăcere-cuvânt, Doinaș remarcă, la nivelul întregii opere blagiene, frecvența termenului „rai” ce trimite la spațiul paradisiac, la situarea în Increat, în opoziție cu frecvența termenilor din sfera decadenței, „căderii în păcat” care vizează asumarea față de condiția inferioară (efemeră), cât și reducerea individului la temporalitate (111). Studiul nostru se va axa, mai departe, pe analiza stilistică şi detalierea câtorva contexte biblice identificate prin intermediul acestui distant reading. 
De pildă, poezia Lumina aduce în discuție mitul genezei universului, comparând lumina din ochii îndrăgostitului cu cea care este precipitată de acest eveniment de-a dreptul glorios (,Lumina ce-o simt năvălindu-mi în piept când te văd/ oare nu e un strop din lumina/ creată în ziua dintâi,/ din lumina aceea-nsetată adânc de viață?’). Cum altfel să prezinte poetul o trăire atât de răsunătoare, nașterea sentimentului de adorație, decât printr-o analogie, una de-a dreptul emblematică, trecerea de la nimicnicie, agonie, la ,viforul” intempestiv al luminii, generat de „Nepătrunsul”, sau figura divină a acestei poezii? Odată cu apariţia luminii, afectivitatea este cea care ia locul letargiei ce domina întunericul; apare astfel dorința (în definitiv o abatere gravă în cultura creștină, descoperind noi sensuri în limitele poeziei), marcată printr-o dublă enumerație, întărită de anafora „o sete” („o sete era de păcate, de doruri, de-avânturi, de patimi,/ o sete de lume și soare.’).

Făcând trecerea la poezia Vreau să joc!, ideea de iminent rămâne prezentă, eul liric luând de această dată frâiele propriului destin, refuzându-și tacit condiția (,săgeată vreau să fiu, să spintec/ nemărginirea”). Prima secvență propune imaginea unui Dumnezeu ferecat în închisoarea lăuntrică a eului poetic, aşadar, impropriu spus, umanul ia locul inumanului. Raportul de superioritate pare să se modifice subit; omul nu mai este „robul”, ci divinitatea este cea preschimbată, în contextul dedublării celor două personalităţi: „,Să nu se simtă Dumnezeu/ în mine/ un rob în temniță - încătușat”. Finalul acutizează acest raport de identificare cu cel aflat inițial pe plan superior: „,ca să răsufle liber Dumnezeu în mine,/ să nu cârtească:/ «Sunt rob în temniță!»”.

Registrul tematic devine cu atât mai impresionant în cadrul poeziei $E v a$, atât titlul cât și conținutul trimițând la mitul păcatului arhaic. Creația debutează brusc, prin pătrunderea intrusului, simbolul demonic al amăgirii, șarpele, care în acest episod liric ademenește figura feminină a Edenului fără remușcări, fapt remarcat prin imaginea auditivă regăsită în comparația ,glasul [...]/ ca un clopoțel de-argint”. În Biblie, argintul nu simbolizează doar bogăția, ci și prețiozitatea adevărului: „Cuvintele Domnului sunt cuvinte curate, un argint lămurit în cuptor de pământ şi curăţit de şapte ori” (Ps. 11:6), însă, în secvenţa blagiană, acest metal pare să dezvolte conotaţii negative, fiind instrumentul ispitei. Motivul șoaptei gravate în enigmă vizează strict părtaşii episodului (șarpele și Eva), Adam fiind exclus temporar (,Şi Eva n-a voit s-o spună nici lui/ Adam”), iar însăşi figura divinităţii neavând acces la mijlocul elucidării şoaptei pline de venin („Nici Dumnezeu n-a auzit ce i-a șoptit anume,/ cu toate că a ascultat și el.”), acest lucru putând fi explicat printr-o interferență cu aria destinului. Cei doi muritori, Adam și Eva, par să fie de la bun început meniți să cadă în păcatul curiozității, aflării veridicității, cu adevărat adepți inconștienți ai 
cunoașterii paradiziace. Ultima strofă a poemului este construită sub formă mitizantă, transferândule reprezentantelor de gen feminin această interferență cu cripticul, dobândită în mod ireversibil prin blestemul sacru abătut asupra înaintașei lor (,că ea știe ceva/ ce noi nu știm,/ ce nimenea nu ştie, nici Dumnezeu chiar”).

În mod impresionant, volumul lui Blaga întrunește și o perspectivă subsidiară, de ce nu, în oglindă, acestei perspective, fapt confirmat prin prezența poemului Legenda. Încă din titlu, poetul dorește să sublinieze caracterul proverbial al figurilor utilizate în acest poem, Eva fiind, însă, descrisă în chip idealizant: „Strălucitoare-n poarta raiului/ sta Eva”, pe când șarpele își păstrează valențele de instigator („,mușca din mărul/ ce i l-a-ntins ispita șarpelui”). Mărul simbolizează aici, prin raport de subordonare, frontiera dintre Vechiul Testament („Eva [...]/ mușca din mărul/ ce i 1a-ntins ispita șarpelui”) și Noul Testament („Un măr crescu acolo - și alții îl urmară [...]/ Și trunchiul aspru și vânjos al unuia din ei/ a fost acela/ din care fariseii meșteri/ ciopliră crucea lui Isus"), remarcându-se o trecere similară conceptului descris în teoria sistemelor complexe, trimițând chiar la „efectul fluturelui”, unde un eveniment, în aparență, complet nesemnificativ (,un sâmbure i-ajunse între dinţi din fructul blestemat./ Pe gânduri dusă Eva îl suflă în vânt”), poate avea urmări de-a dreptul dezastruoase (trunchiul din care a fost cioplită crucea lui Isus este, în poezie, „strămoșul” acestui „măr primordial”). Ultimele două versuri propun un savuros contrast, dintre non-culorile alb (dinții Evei) și negru (sâmburele), un dublet ce se împletește armonios cu această scenă de săvârșire a greșelii colosale, de a pune la încercare răbdarea zeilor.

Consecința acestei greșeli se regăsește, de asemenea, în poemul Lacrimile. Titlul este sugestiv, trimițând la una dintre cele mai compătimitoare episoade din cuprinsul biblic, mai precis exilul primelor ființe umane din „cuibul veșniciei”, din Eden, acest poem focalizându-se însă pe perspectiva adamică, excluzând, de această dată, valența feminină. Pedeapsa divină nu se rezumă însă doar la acest surghiun ireversibil, ci capătă o intensitate de proporții tocmai prin cruzimea cu care este întărită și în mediul terestru. „Omul cel dintâi” este înconjurat de elemente vizuale (enumerația „lumina, zarea, norii - și din orice floare”) care îi activează negreșit memoria afectivă, fapt marcat prin imaginea metaforică a săgeții, obiect iminent ce străpunge, în acest caz, conștiința (,îl săgeta c-o amintire paradisul”), generând astfel o suferință pe care acest „pribeag” nu și-o poate manifesta direct („,nu știa să plângă”). Acesta este, de fapt, momentul în care figura adamică își împlinește condiția lamentabilă, secvența fiind continuată printr-un episod de-a dreptul oedipic; muritorul cere înaltului să-i fie luat simțul vederii („Stăpâne, ia-mi vederea,/ ori dacă-ți stă-n putință împăienjenește-mi ochii/ c-un giulgiu”) pentru a putea face față luminii neîndurătoare („căci, vezi 
- lumina lor mă doare"). Eul este prizonierul unui microunivers al amintirilor, construit prin imaginea florilor, ce evocă, de altfel, efemeritatea ființei, imaginea cerului, însoțit de nori, care trimite la ideea de pierdere a dreptului la veșnicie, într-un final fiind menționată chiar Eva, zâmbetele acesteia marcând adulația pe care i-o poartă în continuare suferindul. Contextul nefast, dar și rugămintea arzătoare a celui menționat anterior obțin o fărâmă de îndurare din partea „Milostivului”, individului acordându-i-se în sfârșit capacitatea de a plânge. Se observă, astfel, câtă putere deține divinitatea, asupra omului și în raport cu acesta, putând chiar să dicteze dacă îi este acordată șansa la ispășire, sau dacă este condamnat la suferința eternă pricinuită în acest caz de „lumina” mult prea puternică a ceea ce a aparținut odată întru totul bărbatului, și la care nu va mai putea avea acces niciodată. Puterea sa se rezumă și la simplul dar către omenire al frumosului prezent pretutindeni, al esteticului regăsit nu numai în lumină, cât și în cel mai adânc hău, în despicătura cripticului. Acest lucru este ilustrat în poezia $\mathrm{Nu}$-mi presimți?, unde ființa iubită apare ca un însemn al existenței mirificului; privind-o, cu toate aspectele ei tainice, reacția de surpriză a eului este de la sine înțeleasă, neexistând o dovadă mai clară de dar al divinității, decât iubita însăși: (,şi-ți zic:/ O, niciodată n-am văzut pe Dumnezeu mai mare!?”).

Printre cele mai importante elemente ce figurează în această poetică a sacralității se regăsește și perspectiva dubletului antitetic rai-iad, întâlnită în primă instanță în poemul Lumina raiului, poem care, surprinzător, conturează dogma interdependenței (binele nu poate să existe fără ca întâi să fie săvârșit răul, drept contraexemplu), a unui eu care aderă la alt tip de credință (,Sunt beat de lume și-s păgân!"), comițând erezia în mod conștient și chiar intenționat, pentru că perspectiva creștină nu îi oferă substratul slăbiciunilor cărora vrea cu ardoare să se lase pradă („Dar oare ar rodi-n ogorul meu/ atâta râs făr' de căldura răului?"). De asemenea, imaginea iubitei este divinizată, prin substantivul în vocativ „sfânto”, lăsându-se totuși loc aceleiași idei de cădere, în cel mai dulce păcat, al dragostei (v. tomber amoureux), eliminându-se ideea emfatică, aproape absurdă a unei virtuți angelice, neprihănite (,Şi-ar înflori pe buza ta atâta vrajă,/ de n-ai fi frământată $[\ldots] /$ de voluptatea-ascunsă a păcatului?’”). Poate de aceea, în continuare, apare întrebarea aproape arzătoare a vocii poetice, „De unde-și are raiul - lumina?”, propunând și un răspuns pe care acesta îl cataloghează drept gândul unui eretic autentic: „,- Știu: îl luminează iadul/ cu flăcările lui!”, închizând totodată atomul acestui dublet, demonstrând coexistența unei valori și a unei anti-valori, între cele două existând un raport de complementaritate. Raiul este văzut aici ca un spațiu lipsit de lumină, poate, prin analogie, un spațiu rece, în contrast cu flăcările imperisabile ale infernului, care emană căldura lor până în orizontul veșniciei. 
Această osmoză dintre poetica blagiană și planul sacru își regăseşte un deplin apogeu în cadrul poemelor Inima și Pax magna. De pildă, poezia Inima constituie un câmp comun pentru granițele păgâne cât și cele biblice, arătând că acestea aderă la aceeași valoare inestimabilă marcată simbolic prin figura inimii. Inima este, printre altele, miezul însuflețit al creației de lut, din care purcede prima încercare de sfidare a celestului, remarcându-se episodul homeric al furtului focului din Olimp de către titanul Prometeu, după cum este ilustrat în secvența: „O, inima [...]/ din lutul ei/ a fost făcut pe vremuri vasul,/ în care Prometeu a coborât din cer/ aprinsul jar ce l-a furat din vatra zeilor”. Prometeu riscă astfel furia zeilor, pedeapsa cruntă și neîndurătoare a acestora, pentru a veni în sprijinul umanității, pe care o favorizează negreșit, în calitate de creator al ființelor omenești. Tot din prisma genezei ființei umane, cea de-a treia strofă propune o legendă din cultura egipteană, central fiind motivul lotusului. În cultura menţionată anterior, floarea de lotus are conexiuni cu mitul creației; lotusul a apărut în această lume mitică din nămolul primordial, înaintea a tot ceea ce există, zeul soarelui însuși, creatorul omului (apărut din lacrima sa vărsată asupra florii), fiind născut din floarea în formă de potir. Astfel, lotusul a ajuns să simbolizeze soarele, creația, renașterea (Chevalier și Gheerbrant 231), iar în poezia lui Blaga aceste sensuri se păstrează, lotusul reprezentând nimic altceva decât o altă formă poetică a ,lutului” amintit în strofa precedentă (,,că lutul ei a fost odată un potir de lotus,/ în care a căzut o lacrimă curată ca lumina/ din ochii celui dintâi sfânt și mare visător/ care-a simțit îmbrățișarea veșniciei”). Jocul miturilor trimite, în sfârșit, la Noul Testament, patimile lui Isus, secvența căpătând conotații tragice, întocmai prin legătura dintre sângele celui supus la acest supliciu și motivul central al poeziei, inima, metamorfozată în lut („,ă ea e lutu-n care-odinioară pe Golgota/ s-a scurs șiroaie sângele din trupul lui Isus,/ când ghimpii îl mușcau cu niște ochi de farisei”). Este reluată ideea de geneză, de această dată păstrânduse registrul biblic, ultima strofă propunând un initium novum, un început pus sub semnul transcendentului („când Dumnezeu se va-ndemna/ să fac-o altă lume/ și-o omenire/ din neamuri mari de zei”), în care divinitatea „va plămădi atunci din lutul ei (al inimii, n.n.)/ pe noul Adam”, figură umană emblematică. Personificarea inimii contribuie la derulare aproape electrizantă a miturilor, întocmai prin redarea unei voci lăuntrice acestui organ dinamic; inima mărturisește („Mărturisiri afunde ard în ea”), cântă, șoptește, într-un final ajungând la acțiunea de strigăt („,ând pieptul ea mi-1 sparge cu/ bătăi de plumb/ atunci îmi strigă îndrăzneață”), voind parcă să semnaleze importanţa spuselor sale cu privire la origini și finalități care îngreunează conștiinţa eului. Simetria compozițională este redată prin plasarea exclamației retorice „O, inima”, la începutul fiecărei strofe, cu scopul de a introduce în planul poetic acest organ vivifiant, sediul afectiv al amintirilor. 
Cât despre poemul Pax magna, perspectiva biblică interferează cu imaginea unui eu ce tinde spre două valori antagonice, ce țin atât de divin, cât și de obscur, producându-se un ușor efect de identificare cu cele două. Rezultatul nu este unul ce ține de narcisism, ci, din contră, ideea de dualitate asumată îi transferă eului poetic capacitatea de a înţelege că cele două forme de existenţă sunt absolut interdependente. Poemul debutează, astfel, cu perspectiva angelică, în care eul liric se transpune, ajungând, chiar, la glorificarea sinelui: ,mă simt un picur de dumnezeire pe pământ/ șingenuchez în fața mea ca-n fața unui idol”. Metafora surprinzătoare din secvența ,-ntr-o mare de lumină mi se-neacă eul” amplifică fundalul acestei perspective calde, caracterizată prin lumina specifică verii, dar și prin indicii cu privire la mediul diurn. Proiectată în divergență, cea de-a doua strofă ilustrează perspectiva demonică (,că dracul nicăiri nu râde mai acasă/ ca-n pieptul meu?”), ce întrunește elemente nocturne (sori îndepărtați, lupii, întuneric), cât și invernale, o lume rece, sumbră, care iradiază până în planul lăuntric. Se creează, așadar, un înveliș pozitiv, ce maschează un miez negativ, cele două fiind privite ca un tot unitar (Todoran, Mitul poetic I 268). Cu atât mai mult, eul liric face referire la conflictul biblic arhicunoscut, dintre Dumnezeu și Lucifer (,Pe semne - învrăjbiți de-o veșnicie Dumnezeu și cu Satana”), conflict care pare să își regăsească favorabilul sfârșit, sau, cel puțin, idealul compromis, în existența eului poetic, care se simte pregătit să accepte ambele tabere, în vederea coexistenței intrinseci, semănând, în persoana eului, un set de valori, vizibile în enumerația de la finalul secvenței: ,Și s-au împăcat/ în mine: împreună picuratu-mi-au în suflet/ credința și iubirea și-ndoiala și minciuna". Antinomia devine cu atât mai evidentă în strofa următoare, prin aliajul dintre ,lumină” și ,păcat”, care par să fuzioneze de timpuriu, dintr-un spaţiu ce trimite către păcatul originar, fapt evocat prin imaginea metaforică a șarpelui „,cu solzii de ispită” și antipatia purtată de îngeri față de creatură. Poemul se încheie întocmai cu această iconografie a șarpelui făţarnic, prin epitetul metaforic „ochii de otravă”, pe care îi folosește pentru a pândi „călcâiul adevărului să-1 muște-nveninându-1”, deci pentru a cauza hazard în scopul propriei satisfacții. În plus, având în vedere viziunea lui Heinrich Zimmer asupra minții umane, acesta fiind de părere că zeii cosmici (stăpânii lumii luminoase) simbolizează conștiința individului, pe când zeii întunericului (figurile demonice) nu reprezintă altceva decât inconștientul, Pax magna poate fi privit drept poemul în care figurează în chip imaginar „lupta dintre conștiința și înclinările inconștiente ale omului” (Blaga, Trilogia valorilor II 61-62), pentru că întunericul nu este ,decât o necesară propedeutică a luminii, ca «dialectică a întoarcerii», sau a «reintegrării contrariilor» în lumea ca «tot»» (Todoran, Mitul poetic II 57). 
Concluzionând, amploarea referințelor sacre oferă o perspectivă cu totul unică asupra universului poetic blagian, întocmai prin existenţa acestor nuanţe interpretative, ce se regăsesc mai ales la nivelul volumului Poemele luminii, dar care nu lipsesc cu desăvârșire nici în cazul întregii creații lirice. Ocurența termenilor biblici demonstrează atât gustul poetului pentru transcendent, cât și dorința de situare poetică a individului în absolut, fără a exclude perspectiva unui eu ce tinde spre decadență. O parte dintre secvențele în care se regăsesc termenii menționați anterior par să reprezinte reinterpretări ale episoadelor biblice, fără a se înlătura însă nucleul alegoric semnificativ.

\section{Bibliografie:}

Biblia sau Sfânta Scriptură. București: Editura Institutului Biblic și de Misiune Ortodoxă, 2015.

Blaga, Lucian. Trilogia cosmologică. București: Humanitas, 1997.

---. Trilogia culturii. București: Humanitas, 2011.

---. Opera poetică. București: Humanitas, 1995.

---. Trilogia valorilor. Vol. II: Gândire magică și religie. București: Humanitas, 1996.

---. Trilogia valorilor. Vol. III: Artă și Valoare. București: Humanitas, 1996.

"Lotus." Def. la.Chevalier, Jean și Alain Gheerbrant, Dicţionar de simboluri: mituri, vise, obiceiuri, gesturi, forme, figuri, culori, numere. Volumul II (E-O). București: Artemis, 1994.

Doinaș, Ștefan Augustin. Eseuri. București: Eminescu, 1996.

Petrescu, Alexandru. Lucian Blaga: o nouă paradigmă în filosofia științei. Timișoara: Eurobit, 2003. Print.

Rockwell, Geoffrey. Stéfan Sinclair. Voyant Tools. 2012. Web. 24 octombrie 2020. $<$ https://voyant-tools.org/>.

Todoran, Eugen. Lucian Blaga. Mitul poetic. Vol. I. Timișoara: Facla, 1981.

---. Lucian Blaga. Mitul poetic. Vol. II. Timișoara: Facla, 1983. 